Columbia Law School

Scholarship Archive

2011

\title{
The Paradox of Law Enforcement in Immigrant Communities: Does Tough Immigration Enforcement Undermine Public Safety?
}

\author{
David Kirk \\ david.kirk@sociology.ox.ac.uk \\ Andrew V. Papachristos \\ andrew.papachristos@yale.edu \\ Jeffrey Fagan \\ Columbia Law School, jfagan@law.columbia.edu \\ Tom R. Tyler \\ tom.tyler@nyu.edu
}

Follow this and additional works at: https://scholarship.law.columbia.edu/faculty_scholarship

Part of the Immigration Law Commons, Law Enforcement and Corrections Commons, and the Public Law and Legal Theory Commons

\section{Recommended Citation}

David Kirk, Andrew V. Papachristos, Jeffrey Fagan \& Tom R. Tyler, The Paradox of Law Enforcement in Immigrant Communities: Does Tough Immigration Enforcement Undermine Public Safety?, CoLUMBIA Public LaW Research PAPER No. 11-281 (2011).

Available at: https://scholarship.law.columbia.edu/faculty_scholarship/1708

This Working Paper is brought to you for free and open access by the Faculty Publications at Scholarship Archive. It has been accepted for inclusion in Faculty Scholarship by an authorized administrator of Scholarship Archive. For more information, please contact scholarshiparchive@law.columbia.edu. 


\section{Columbia Law School}

Public Law \& Legal Theory Working Paper Group

Paper Number 11-281

The Paradox of Law Enforcement in Immigrant Communities:

Does Tough Immigration Enforcement Undermine Public Safety?

David S. Kirk

University of Texas at Austin

Andrew V. Papachristos

University of Massachusetts, Amherst \& Harvard University

Jeffrey Fagan

Columbia University School of Law

and

Tom R. Tyler

New York University

October 4, 2011 


\title{
The PARAdox of LAW ENForCEMENT IN IMMIgRANT CoMMUNITIES:
}

\section{Does Tough Immigration ENForcement Undermine Public SAFety?}

\author{
David S. Kirk ${ }^{\mathrm{a}}$ \\ Andrew V. Papachristos ${ }^{b}$ \\ Jeffrey Fagan ${ }^{c}$ \\ Tom R. Tyler ${ }^{d}$
}

${ }^{\text {a }}$ University of Texas at Austin

${ }^{\mathrm{b}}$ University of Massachusetts, Amherst and Harvard University

c Columbia University

${ }^{\mathrm{d}}$ New York University 


\title{
The Paradox of Law Enforcement in Immigrant Communities: Does Tough Immigration Enforcement Undermine Public Safety?
}

\begin{abstract}
Frustrated by federal inaction on immigration reform, several U.S. states in recent years have proposed or enacted laws designed to stem the flow of illegal immigrants into the U.S. and to facilitate their removal. An underappreciated implication of these laws is the potential alienation of immigrant communities — even law abiding, cooperative individuals_-from the criminal justice system. The ability of the criminal justice system to detect and sanction criminal behavior is dependent upon the cooperation of the general public, including acts such as the reporting of crime and identifying suspects. Cooperation is enhanced when local residents believe that laws are enforced fairly. In contrast, research reveals that cynicism of the police and the legal system undermines individuals' willingness to cooperate with the police and engage in the collective actions necessary to socially control crime. By implication, recent trends toward strict local enforcement of immigration laws may actually undercut public safety by creating a cynicism of the law in immigrant communities. Using data from a 2002 survey of New York City residents, this study explores the implications of perceived injustices perpetrated by the criminal justice system for resident willingness to cooperate with the police in immigrant communities.
\end{abstract}

Keywords: immigration, legal cynicism, legitimacy, cooperation, procedural justice 
Since the tragic 9/11 terrorist attacks, the number of yearly deportations of illegal aliens has more than doubled in the U.S., rising from 165,000 deportations in 2002 to nearly 400,000 in 2009 (U.S. Department of Homeland Security [DHS] 2010). A vast majority of this increase can be attributed to the growing number of non-criminal aliens now being deported. In fact, sixtyseven percent of deportations in 2009 were of non-criminal immigrants. Not surprisingly then, fears of deportation are prevalent in immigrant communities, especially given recent political shifts in many states toward increased enactment and enforcement of immigration laws. For instance, in a 2009 evaluation of the federal 287(g) program — which expands the authority of local and state law enforcement officials to enforce civil immigration violations-the U.S. Government Accountability Office (GAO) reported evidence of considerable fear among community residents that police would deport individuals because of incidents as minor as a traffic violation (GAO 2009). Similar concerns were recently expressed by community stakeholders and interested parties in public hearings conducted by a federal task force assigned to review the U.S. Immigration and Customs Enforcement's (ICE) Secure Communities program—which facilitates the sharing of fingerprint information between the Federal Bureau of Investigation and ICE (Homeland Security Advisory Council 2011).

In spite of the growing use of deportation as an enforcement tool, numerous states over the past several years have grown frustrated with federal inaction on immigration reform and have proposed or enacted their own measures to stem the flow of illegal immigrants into the U.S. and to facilitate their removal. For example, Arizona Senate Bill 1070 (SB 1070), passed in April 2010, set an early precedent. This law mandates local law enforcement to detain individuals suspected of being in the U.S. illegally. Alabama, Georgia, Indiana, South Carolina, and Utah all have recently passed copycat bills and several other states are eyeing similar measures. Not to be 
outdone, an even newer wave of proposed reforms in Arizona and other states aim to sanction illegal immigration by withdrawing the citizenship of U.S. born children if their parents are illegal immigrants.

As the next presidential election nears and rhetoric on immigration intensifies, it is an opportune time to assess the potential unintended consequences of increasing enactment and enforcement of punitive immigration laws. The criminal justice system depends on the cooperation of the general public to detect and sanction criminal behavior (Skogan and Frydl 2004). Cooperation is enhanced when local residents believe that laws are enforced fairly and when law enforcement officers pursue "procedural justice” in their everyday contacts with residents (Fagan and Meares 2008; Tyler and Fagan 2008; Tyler 2010). Yet increased and harsh enforcement of laws may undermine the ability of the police to control crime by reducing the willingness of immigrants to report crimes and cooperate with the police in criminal investigations. Recent studies show that cynicism of the police and the legal system not only leads to an increased likelihood of neighborhood crime and violence, but also undermines individuals' willingness to cooperate with the police and engage in the collective actions necessary to socially control crime (Sampson, Morenoff, and Raudenbush 2005; Tyler and Fagan 2008; Kirk and Matsuda 2011; Kirk and Papachristos 2011; Papachristos, Meares, and Fagan 2011; Sampson 2011). Thus, while strict immigration laws are often touted politically as ways to ensure public safety, the enactment and enforcement of harsh immigration laws may actually undercut public safety by creating a cynicism of the law in immigrant communities.

This study examines the extent to which a cynicism of the law characterizes immigrant communities in the U.S., and, more importantly, the extent to which the actions of law enforcement influence resident cynicism. We pay particular attention to the consequences of 
cynicism of the law in immigrant communities, focusing on the willingness of residents to report crimes and assist the police in locating individuals suspected of committing crimes.

\section{BACKGROUND}

Immigrants in the U.S. have a complex, if not tenuous, relationship with the law. On the one hand, many immigrants come to the U.S. for the protections of the very laws that make this country great: freedom of speech, religion, due process, assembly, and other rights guaranteed by the Constitution and upheld by our legal institutions. Immigrants are generally a self-selected group whose motivations for relocation to the U.S. suggest that their social and political values are compatible with the moral underpinnings of American laws. Not surprisingly, then, first generation immigrants tend to be less criminally-inclined that native-born blacks, Hispanics and whites, a research finding that has been replicated time and again in studies over the past one hundred years (U.S. Immigration Commission 1911; Wickersham Commission 1931; Sampson, Morenoff, and Raudenbush 2005; Morenoff and Astor 2006).

On the other hand, immigrants have reason to be wary of American legal institutions, and especially the police. Both the civil and criminal legal systems in the U.S. often treat immigrants more harshly than native-born citizens, even though immigrants are generally less crime-prone and more attentive to civil legal obligations. From the Naturalization Act of 1790 and the 1882

Chinese Exclusion Act to the Patriot Act, immigrants face greater intrusions on their privacy and considerably higher penalties and legal consequences for their actions, at times without the due process granted to native-born citizens. Several court cases, from Korematsu v U.S. (1942) to Martinez-Fuerte v U.S. (1973) and U.S. v Brignoni-Ponce (1975), have sanctioned statutory barriers to full equality for immigrants. 
As noted, the latest movement in immigration reform has been dominated at the state level due to the perceived inaction at the federal level. Arizona SB 1070 has been a trailblazer for subsequent laws. It specifies, among other provisions, that law enforcement must make efforts to determine the immigration status of individuals during an arrest or lawful stop if they have reasonable suspicion that the individual is an illegal alien. In July 2010, one day before the law was to take effect, a federal district court judge struck down key provisions of the bill, with the ruling subsequently appealed by the State of Arizona. In April 2011, the U.S. Court of Appeals for the Ninth Circuit rejected the appeal and let stand the lower court's decision. In August 2011, Arizona Governor Jan Brewer appealed to the U.S. Supreme Court, asking for the Court to overturn the decision of the lower court.

The potential consequences of the passage and enforcement of immigration laws such as Arizona Senate Bill 1070 are as of yet unknown. At a minimum, the assignment of immigration enforcement to local police may overburden law enforcement agencies already struggling to enforce criminal statutes in the wake of economic crises and declining tax revenues. ${ }^{1}$ This expansion of the mission of local law enforcement may have complications that its proponents may not have anticipated. One potentially significant by-product of such enforcement is the changing of attitudes towards the law, legal authority, and especially the police in immigrant communities.

A robust body of research shows that the cooperation of the general public to detect and sanction criminal behavior is critical to effective law enforcement (Skogan and Frydl 2004; Tyler 2010). Other studies show that cooperation as well as compliance with the law is enhanced

\footnotetext{
${ }^{1}$ In fact, in some small jurisdictions_-including Alto, Texas; Wells, Texas; and Half Moon Bay, California-local police departments have been completely disbanded or furloughed in recent months because cities simply could no longer afford to maintain a police force given the economic downturn. Many other police departments have cut positions, yet are now being called upon to engage in immigration enforcement.
} 
when local residents believe that laws are enforced fairly and when law enforcement officers pursue procedural justice in their everyday contacts with citizens (Sunshine and Tyler 2003; Fagan and Meares 2008; Tyler and Fagan 2008; Tyler 2010). This connection between procedural justice and cooperation and compliance has been found among adults but also children and adolescents, thereby revealing that procedural justice and the resulting process of legal socialization are core components of child development (Fagan and Tyler 2005; Fagan and Piquero 2007). Procedural justice in turn promotes shared perceptions that the law and legal actors are legitimate, leading to shared obligations to both cooperate with legal actors and to abide by legal codes. For instance, Tyler, Schulhofer, and Huq (2010) find that MuslimAmerican residents of New York are more likely to cooperate with the police when they view the police as a legitimate and just authority.

Whereas belief in the fairness of the law and legal procedures increases cooperation with police and legal authorities, the converse might also be true: unduly harsh laws and legal procedures may produce cynicism of the law and legal institutions. This may be increasingly true in immigrant communities which face heightened scrutiny and an intensified police gaze. In these communities, harsh policing and legal efforts may be viewed as unjust and thereby undermine the ability of the police to control crime by reducing the willingness of immigrants to report crimes and cooperate with the police in criminal investigations. Thus, a paradox arises: harsh legal sanctions against immigrants are often framed as a means to keep communities “safe,” yet they may in fact have the opposite effect by decreasing cooperation with police. In fact, recent studies show that cynicism of the police and the legal system not only leads to an increased likelihood of neighborhood crime and violence, but also undermines individuals’ willingness to cooperate with the police and to engage in the collective actions necessary to 
socially control crime (Tyler and Fagan 2008; Sampson, Morenoff, and Raudenbush 2005; Kirk and Matsuda 2011; Kirk and Papachristos 2011; Sampson 2011).

Legitimacy and legal cynicism work in tandem to either strengthen or corrode the relationships of citizens to the law. ${ }^{2}$ Legitimacy is the property that a rule or an authority has when others feel obligated to voluntarily defer to that rule or authority. In other words, a legitimate authority is an authority regarded by people as entitled to have their decisions and rules accepted and followed by others (see, e.g., French and Raven 1959). The roots of the modern discussion of legitimacy are usually traced to Weber's writing on authority (Weber 1968) and to Beetham’s (1991) dynamic theory on the political economic conditions under which citizens consent to authority. Legitimacy, therefore, is a quality possessed by an authority, a law, or an institution that leads others to feel obligated to obey its decisions and directives.

The legitimacy of authority is a product of the means by which that authority is utilized. Individuals are more willing to accept decisions of law enforcement if they think the police are acting in a just manner (Tyler 1990). In fact, evidence suggests that assessments of whether or not a law or legal actor is considered "just” is more strongly linked to perceptions of police legitimacy than are evaluations of their effectiveness in controlling crime. There are several elements to individuals’ assessment of procedural justice. First, views of justice will be enhanced when individuals are allowed to provide input into the justice process, particularly in investigations that involve themselves. Similarly, if individuals are treated with respect and dignity by legal officials, they are more likely to judge the police as a just institution. Finally, if law enforcement authorities are trustworthy and act in a fair and neutral manner, individuals are

\footnotetext{
${ }^{2}$ Legitimacy and cynicism are not necessarily two sides of the same coin, and while sharing some predicates, such as evaluations of procedural justice, they also reflect other ex ante views of police and of law that are modifiers of how citizens perceive and value law. See, Tyler and Fagan (2008) and Fagan and Piquero (2007) for examples of the complex relationship between legitimacy and legal cynicism.
} 
more likely to conceive of the police as just and ultimately as a legitimate authority. In short, the police and other agents of the justice system can facilitate cooperation with the law and compliance with it by conducting their operations in ways that the public deem fair and just (Tyler 1990).

Legal cynicism occurs when people perceive the law, and the police in particular, as illegitimate, unresponsive, and ill-equipped to ensure public safety (Kirk and Papachristos 2011). This cynicism often is the product of societal structural conditions (such as concentrated poverty) and resident interactions with the justice system, but also unfair treatment by legal actors (Sampson and Bartusch 1998; Fagan and Piquero 2007; Tyler and Fagan 2008; Kirk and Papachristos 2011). In socially and economically disadvantaged neighborhoods, people come to perceive that the dominant societal institutions (of which the police and the justice system are emblematic) will offer them little in the way of security, either economic or personal. In particular, harassing behavior by the police and insufficient or ineffective crime control breeds cynicism (Fagan and Meares 2008; Tyler and Fagan 2008). Through interaction among neighborhood residents, cynicism of the law can become embedded into the culture of a community. In this way, legal cynicism represents a quality of neighborhoods, and not simply the views of a particular individual (Sampson and Bartusch 1998; Kirk and Papachristos 2011). In turn, crime may flourish in neighborhoods characterized by a culture of cynicism, yet because of legal cynicism these crimes may go unreported and therefore unsolved.

These perspectives on justice, legitimacy, and legal cynicism are especially salient for immigrants who may face greater exposure to and contact with the police. Not only does one's status as an immigrant demark him or her for more focused legal attention, but immigrants also tend to settle in areas within cities that experience high levels of ecological risk factors known to 
predict crime and other social problems. In other words, immigrants may become more susceptible to legal cynicism because of their individual status as well as their ecological position within a city. One implication of legal cynicism is that intensive local enforcement of immigration laws, and order maintenance policing strategies more generally, could potentially undermine the ability of the police to control crime in neighborhoods with high concentrations of immigrants because of reduced public cooperation. If enforcement of immigration laws weakens perceptions of fairness and legitimacy, and thereby prompts a cynicism of the law, then the very public safety that police practices are designed to protect may evaporate.

In the analysis that follows, we examine the relationship between immigration, procedural justice, legal cynicism, and public cooperation with the law. The conceptual model in Figure 1 provides a visual synopsis of the discussion above, and guides our ensuing analysis. We assess the extent to which a cynicism of the law characterizes immigrant communities, and seek to determine whether the prevalence of just and fair police practices mediates this association. Importantly, in our model there is a dualism to justice. Perceptions of fairness, particularly for foreign-born populations, reflect characteristics of the justice system in the U.S. but also sending societies. Yet the direction of this "halo effect" is not altogether clear. On the one hand, having been born within and experienced a repressive society and government may have a lasting negative effect on an immigrant's general perception of authority institutions (Tyler, Schulhofer, and Huq 2010). Indeed, experience with oppressive regimes in countries of origin may be one of the "push" factors driving immigration, yet which continues to influence perceptions of authority among immigrant communities even after they are well established in the U.S. On the other hand, perceptions of injustices in origin countries may lead immigrants to have positive views about the U.S. justice system because the U.S. is perceived to be a relatively more equitable and 
just society. This may be true even if immigrants are denied the full rights and protections enjoyed by citizens of the U.S. After analyzing the determinants of legal cynicism, we then explore the extent of public cooperation with the law in immigrant communities, and the extent to which a cynicism of the law undermines this cooperation.

[Figure 1 about here]

\section{SOURCES OF DATA}

Data utilized in this study come from the 2000 U. S. Census, the World Bank’s World Governance Indicators project, and a 2002 survey of New York City residents (see Sunshine and Tyler 2003). For the survey, a total of 1,653 respondents were drawn via a stratified random sample of residential telephone numbers in the City. Interviews were conducted in English or Spanish, per the language preference of the respondent. Interviews were conducted with the adult in the household with the most recent birthday. The response rate for the survey was 64 percent of eligible respondents. Survey questions included, among others, items about police legitimacy, legal cynicism, and willingness to cooperate with the police to fight crime.

Our units of analysis are neighborhoods consisting of several census tracts each. Our units were drawn from New York City neighborhood boundaries defined by Kenneth Jackson and John Manbeck (1998) based on interviews with local residents and a physical examination of the neighborhoods. ${ }^{3}$ These boundaries form "natural" areas within the city with a community history and identity among residents (see Figure 2 for a map of the distribution of 2000 foreignborn population across these neighborhoods in the five New York boroughs). We geocoded the location of the 1,653 respondents, and then assigned them to their respective neighborhood. Our

\footnotetext{
${ }^{3}$ We thank Amanda Geller for assistance with data preparation and the constructions of our units of analysis.
} 
survey sample is spread across 227 neighborhoods (out of 295 total in New York City), with 79 of those neighborhoods containing 8 or more survey respondents. We drop those neighborhoods from our analysis with fewer than 8 respondents. ${ }^{4}$

[Figure 2 about here]

\section{VARIABLES}

The variables we use in our analyses can be categorized into 4 broad classes: immigration measures, neighborhood structural characteristics, neighborhood disorder, and perceptions of the criminal justice system.

We measure immigration by three different dimensions, all derived from U.S. Census data. First, IMMIGRANT CONCENTRATION represents a combined measured of the percent of foreign-born residents in the neighborhood and linguistic isolation. The latter is an indicator of the percent of households in which no person age 14 or older speaks English very well. In analyses, we use measures for the years 1990 and 2000, as well as a measure of the residual change from 1990 to 2000. ${ }^{5}$ We created our IMMIGRANT CONCENTRATION scale via principal components analysis. Specifically, we pooled data from both years into the same dataset (i.e., each neighborhood had two observations). By doing so, the factor loadings for each of the census items do not vary across the two time points, thus ensuring comparability across time. Second, we include a measure of RECENT IMMIGRANTS, which represents the percent of foreign-born population in a neighborhood in the year 2000 who had arrived in the U.S. within the previous 5

\footnotetext{
${ }^{4}$ We selected 8 respondents as our cutoff point in order to retain at least 25 percent of the New York City neighborhoods in our sample. Nevertheless, we also conducted our analysis using 10 respondents as the cutoffresulting in 53 neighborhoods-with comparable statistical inferences.

${ }^{5}$ This is computed by regressing the 2000 value of immigrant concentration on the 1990 value, and outputting the unstandardized residual.
} 
years. Third, we construct a measure of LANGUAGE DIVERSITY in a neighborhood in a similar manner as in Graif and Sampson (2009). It measures the diversity of languages spoken among residents of a neighborhood, per 2000 Census data, and is computed as one minus the Herfindahl index. ${ }^{6}$ The index is a product of both the total number of languages spoken in a neighborhood and the evenness in the proportion of residents who speak each language. Conceptually, there is overlap in our measures of immigrant concentration and language diversity, such that a neighborhood with much language diversity is likely to have a concentration of foreign-born residents. However, there are also relatively homogenous immigrant communities with most residents from the same sending country or region. In such cases, concentration would be high but diversity would be low. Measuring both immigrant concentration and language diversity allows us to assess these different dynamics of immigration. The most common of the fifty-eight reported languages spoken in New York City are English, Spanish, Italian, Chinese, Russian, Polish, German, Korean, and Hebrew. Among the most linguistically diverse neighborhoods in New York City are Borough Park and Kensington in Brooklyn, and Flushing, East Flushing, and Queensboro Hill in Queens. In sum, these three measures capture the spatial concentration of immigrants in New York as well as the diversity of immigration status and the sending countries. Neighborhood structural data come from the 2000 U.S. Census. Consistent with prior work on neighborhoods and crime, we utilize three measures of neighborhood structure: CONCENTRATED POVERTY, RESIDENTIAL INSTABILITY, and POPULATION DENSITY. CONCENTRATED POVERTY is a scale of economic disadvantage in a given neighborhood created via principal components analysis, based on the following indicators: the percentage of families below the

\footnotetext{
${ }^{6}$ Language diversity is computed as follows: $L_{t}=1-\left(\sum s_{r}^{2}\right)_{t}$ where $t$ references the neighborhood, $r$ refers to the languages in the neighborhood, and $s_{r}$ represents the proportion of the neighborhood population that speaks a given language at home.
} 
poverty line, of families receiving public assistance, of unemployed individuals in the civilian labor force, of individuals not in the labor force, of female-headed families with children, of neighborhood population between the ages of 5 and 15, of nonwhite population, and income inequality (as measured by the Gini coefficient). RESIDENTIAL STABILITY is similarly created with principal components analysis, based on the following Census items: the percentage of residents five years old and older who lived in the same house five years earlier and the percentage of homes that are owner-occupied. POPULATION DENSITY measures the number of residents per square mile.

NEIGHBORHOOD DisORDER measures the extent of physical and social disorder in a neighborhood, constructed via principal components analysis from responses from the aforementioned survey of New York residents. Respondents were asked how often they see the following objects and occurrences in their neighborhood: (1) garbage in the streets or on the sidewalk, (2) empty beer bottles, (3) graffiti, (4) gangs hanging out, (5) people drinking beer, wine or liquor on the street, and (6) people buying or selling drugs on the street. We include this measure in our analyses to account for instrumental reasons for why neighborhood residents may be cynical of the law and therefore unwilling to cooperate with the law. Legal cynicism may be a product of the effectiveness of the police in eliminating disorderly conditions, in addition to or instead of procedural justice.

We include four different measures of perceptions of the criminal justice system. Two of these measures, ORIgin RULE of LAW and Procedural Justice, contain information about the fairness of the legal system. The former represents perceptions of fairness in immigrants' origin country whereas the latter represents perceptions of the U.S. criminal justice system, specifically related to the police operating in the respondent's neighborhood. Per Figure 1, we argue that 
these dimensions of fairness directly or indirectly predict our other two measures, LEGAL Cynicism and Public CoOperation With the Police.

To construct a measure of rule of law in origin countries of immigrants, we draw upon 2000 data from the World Bank’s World Governance Indicators (WGI) project

(www.govindicators.org). The WGI produces aggregate country-level indicators of several dimensions of governance, culled from a variety of existing data sources. Data sources include the Gallup World Poll (GWP), the World Economic Forum’s Global Competitiveness Report (GCS), and the Economist Intelligence Unit’s Risk-Wire \& Democracy Index (EIU). The rule of law indicator measures "perceptions of the extent to which agents [individuals and organizations] have confidence in and abide by the rules of society, and in particular the quality of contract enforcement, property rights, the police, and the courts, as well as the likelihood of crime and violence” (Kaufmann, Kray, and Mastruzzi 2010, 4). Example indicators include public confidence in the police and justice system (from the GWP), the independence of the judiciary from political influences (from the GCS), and fairness and speediness of the judicial process (from the EIU). We developed a neighborhood-level measure that is the weighted average of origin country RULE OF LAW characteristics among the foreign-born population in the neighborhood. Simply, the greater the representation of a given country among the foreign-born population in a neighborhood (as determined by 2000 U.S. Census data), the more the RULE OF LAW variable will represent the views of the legal system in that origin country.

Procedural Justice, Legal Cynicism, and Public Cooperation with the Police were all constructed with principal components analysis from data from the survey of New York residents. PROCEDURAL JUSTICE measures the extent to which residents regard that the police in their neighborhood act in a fair, respectful, and equitable manner. Respondents were asked the 
frequency with which the police engaged in the following behavior: (1) "Use fair procedures to decide how to handle the problems they deal with," and (2) "Treat people in fair ways." Respondents were also asked the extent to which they agree with the following statements about police behavior: the police (3) "Consider the views of the people involved when deciding what to do," (4) Take account of the needs and concerns of the people they deal with,” (5) "Treat people with dignity and respect,” (6) “Respect people’s rights,” (7) Usually accurately understand and apply the law," (8) "Make their decisions based upon facts, not their personal biases or opinions," (9) "Try to get the facts in a situation before deciding how to act," (10) "Give honest explanations for their actions to the people they deal with,” and (11) “Apply the rules consistently to different people.”

To measure LEGAL CYNICISM we combine four items from our survey. ${ }^{7}$ Respondents of the survey were asked the extent to which they agree to the following: (1) "Sometimes you have to bend the law for things to come out right," (2) "The law represents the values of the people in power, rather than the values of people like you,” (3) "People in power use the law to try to control people like you,” and (4) “The law does not protect your interests.”

Willingness of residents to cooperate with the police to fight crime and solve existing crimes (i.e., PUBLIC COOPERATION WITH POLICE) is measured from three items designed to ask respondents how likely they would be to: (1) "Call the police to report a crime occurring in your neighborhood," (2) "Help the police to find someone suspected of committing a crime by

\footnotetext{
${ }^{7}$ We utilize an operationalization of "legal cynicism" which differs to some degree from measurements employed in previous research on legal cynicism, but nevertheless measures cynical perceptions of the legitimacy and equitability of the law. Sampson and Bartusch (1998), Fagan and Tyler (2005), and Fagan and Piquero (2007) use measures that tap a broader construct which combines cynicism of the law with moral cynicism and anomie, whereas Kirk and Papachristos (2011) more narrowly focus on perceptions of the "legal" system and the police in particular. The measure we use here similarly provides a narrow focus on legal cynicism, but does not focus specifically on perceptions of the police.
} 
providing them with information," and (3) "Report dangerous or suspicious activities in your neighborhood to the police."

\section{CYNICISM OF THE LAW IN IMMIGRANT COMMUNITIES}

Table 1 presents results of our statistical analysis of legal cynicism. ${ }^{8}$ Findings from Model 1 reveal that residents of impoverished neighborhoods are much more likely to be cynical of the law than residents of more affluent areas. Net of other neighborhood characteristics, the extent of disorderly conditions in a neighborhood appears to have little influence on cynical perceptions of the law. Results from Model 1 also importantly demonstrate a negative relationship between immigrant concentration and legal cynicism: neighborhoods characterized by a high concentration of foreign-born residents are less likely to be cynical of the law than in neighborhoods with lesser concentrations. One interpretation of this finding is that acculturation begets a greater cynicism of societal institutions, particularly the law. In preliminary analysis, we also included an interaction term between concentrated poverty and immigrant concentration to determine if the relationship between immigration and legal cynicism is dependent upon the level of neighborhood poverty. However, we found no significant interaction effect. Overall, the $R$-squared statistic reveals that we have explained 51 percent of the variation in legal cynicism across neighborhoods with the predictors included in Model 1.

To unpack the reasons for the negative relationship between concentrated immigration and legal cynicism, we examine the role of language diversity, recent immigration, and the extent of change in the neighborhood proportion of foreign-born residents. Model 2 shows that

\footnotetext{
${ }^{8}$ All models in Tables 1-3 were estimated with via a least squares regression with robust standard errors. Robust standard errors are useful for accounting for heteroskedasticity, and yield a more conservative test of statistical significance than otherwise.
} 
the extent of ethnic diversity in a neighborhood is unrelated to legal cynicism. ${ }^{9}$ Similarly, in Model 3 we can see that the extent to which the foreign-born population is dominated by recent arrivals (within the past 5 years) is unrelated to legal cynicism. Interestingly, in Model 4 we find that legal cynicism is a product of the proportional size of the foreign-born population in a neighborhood and the extent to which that population has grown over time (1990 to 2000). Immigrant neighborhoods generally have less cynicism of the law than in neighborhoods populated predominantly by native-born groups, and cynicism is even lower in neighborhoods where the relative size of the immigrant population is growing. That said, while statistically significant, adding a measure of the growth in the proportion of the immigrant population does not add to the amount of variability in legal cynicism that we have explained (i.e., 51 percent, just as in Model 1).

[Table 1 about here]

Table 2 considers how perceptions of justice influence legal cynicism. Model 5 shows, as expected, that legal cynicism varies inversely with perceptions of procedural justice. Neighborhood residents tend to be less cynical of the law when legal procedures are deemed to be fair and just. Yet fair practice by the police in the U.S. is not the only measure of justice with bearing on residents' perceptions of legal cynicism. In Model 6 we see that the fairness of and confidence in the law in countries of birth (i.e., ORIGIN RULE OF LAW) has a strong negative effect on legal cynicism. If a neighborhood is populated by immigrants from countries with a fair

\footnotetext{
${ }^{9}$ Many of our variables are significantly correlated, including immigrant concentration and language diversity. Including highly correlated, redundant variables in a statistical model can potentially inflate the standard errors of our regression parameters. We assessed this potential condition, which is termed multicollinearity, by calculating variance inflation factors (VIF) for all independent variables in all of our models. A high VIF indicates that a given variable is highly correlated with the other independent variables in the model. For all models presented in Tables $1-3$, VIF values all fell well below the generally accepted threshold of 10 , indicating that multicollinearity does not adversely affect the precision of our parameter estimates (Kennedy 1998). Concentrated poverty and residential stability had the highest VIFs, yet with values still below 5 in all models.
} 
justice system and a legitimate rule of law, then residents will generally not be cynical towards the law. Standardized effects presented in Figure 3-which we use to compare the relative importance of different explanatory factors—reveal that only concentrated poverty has a stronger effect on legal cynicism than RULE OF LAW, which is followed closely by procedural justice and immigrant concentration. ${ }^{10}$

[Table 2 and Figure 3 about here]

In summary, our evidence from the largest and most ethnically diverse urban area in the country reveals that cynical views of the law among neighborhood residents are the product of not only perceptions of the police in the U.S., but also origin countries. There is, in a sense, a duality to justice: the immediate institutional and social context is highly relevant for legal cynicism, yet so are prior contexts, in this case the rule of law in countries of origin for immigrant populations. ${ }^{11}$ Nevertheless, controlling for this dual nature of justice, we still find a strong, negative relationship between immigration and legal cynicism. In general, immigrant communities in New York City have less cynicism than areas heavily populated by native groups.

\section{FOSTERING COOPERATION WITH THE POLICE}

We next investigate the relationship between immigration, legal cynicism, and public cooperation with the law. Model 1 of Table 3 reveals that the extent of resident cooperation with police in a neighborhood varies negatively with the level of concentrated poverty yet positively

\footnotetext{
${ }^{10}$ Standardized effects make it possible to compare the effects of variables that are measured on different scales. In the present case, a standardized effect represents the change in legal cynicism, in standard deviations, from a standard deviation increase in an explanatory variable, controlling for the other variables.

${ }^{11}$ In additional analyses, we also include an interaction term between the two measures of justice to assess whether there might be an accentuating or compensatory relationship between the two, yet find no evidence of an interactive effect.
} 
with residential stability. With respect to the latter, residential stability can signify resident investment in the neighborhood, including the development and maintenance of neighborly social ties (Bursik and Grasmick 1993). Cooperating with the police to control crime, then, is a corollary outcome of this investment process.

Findings show a positive relationship between immigrant concentration and public cooperation with the police. Recall that the former is measured by the combination of the percent of foreign-born residents in a neighborhood and linguistic isolation (i.e., the percent of households in which no person age 14 or older speaks English very well). Thus, the greater the percent of foreign-born residents in a neighborhood as well as linguistic isolation, the more likely that residents will cooperate with the police to report crimes and assist the police with solving crimes. Somewhat surprisingly then, even in immigrant neighborhoods where language may be a barrier to communicating with the police, cooperation with the police is rather prevalent. Contrary to some political portrayals of immigrants as being less cooperative with authorities, our findings clearly indicate that residents of immigrant neighborhoods are actually more cooperative with the police than are residents of native-born neighborhoods.

Results in Model 2 indicate that legal cynicism and public cooperation with the police are negatively related, and that legal cynicism partially mediates the relationship between immigrant concentration and public cooperation. Hence, one reason why immigrant communities are generally more cooperative with the police than other types of neighborhoods is because such neighborhood communities are less cynical about the law.

To investigate the relationship between immigration, cynicism, and cooperation with the police while distinguishing between homogenous and heterogeneous immigrant communities, we next add the measure of language diversity to the model. In contrast to our linguistic isolation 
measure, this variable represents the total number of languages spoken in a neighborhood as well the evenness in the proportion of residents who speak each language. We find a negative relationship between language diversity and cooperation with the police, net of the effect of immigrant concentration/linguistic isolation. Ethnic heterogeneity appears to impede communication and interaction among neighborhood residents, thereby undermining processes of informal social control. When neighbors do not know each other or do not communicate with or trust each other, then they are less likely to intervene on behalf of a common good or to collectively solve problems (see Kornhauser 1978; Shaw and McKay 1942). Take, for instance, the following scenario: in a diverse neighborhood that lacks trusting relations between ethnic groups, a resident may fear retaliation or retribution if he or she helps the police solve a crime committed by a member of another group. Because of a lack of trust and shared understanding among neighborhood residents, individuals may be unwilling to expose themselves to potential risks by cooperating with the police, even if they generally hold favorable views of the police and the law. On the other hand, immigrant enclaves characterized by a relatively homogenous ethnic settlement have particularly high levels of cooperation with the police. Remarkably, this is true even in mostly non-English speaking communities where one might assume that language barriers would deter residents from calling the police.

In summary, cooperation with the police is significantly more likely in neighborhoods with concentrations of immigrants, particularly in neighborhoods with a relatively homogenous immigrant community. Yet because cynicism of the law is such a powerful predictor of cooperation with the police, the cooperative, amiable relations found in many immigrant communities between police and residents can easily erode if the perceived fairness and legitimacy of the U.S. justice system decays. Immigration enforcement, particularly those laws 
and initiatives that would inevitably cast a wide net, may alienate the very communities in the U.S. which most reliably work with the police to protect public safety.

[Table 3 about here]

\section{DISCUSSION}

The results of this study shed new light on the way the law is perceived in immigrant communities. Our study finds that immigrant communities, even more so than neighborhoods populated predominantly by native-born citizens, are less cynical of the law and more cooperative with legal authority. To these findings, we again note that a host of social science studies reveal that immigrants, on average, do not commit as many crimes as native-born groups (see, e.g., Sampson, Morenoff, and Raudenbush 2005; Morenoff and Astor 2006). Moreover, neighborhoods characterized by a concentration of immigrants do not have elevated levels of community violence; rather immigration appears to produce a protective effect against violence (e.g., Butcher and Piehl 1998; Hagan and Palloni 1998; Lee, Martinez, and Rosenfeld 2001; Davies and Fagan 2012). This growing body of social science research, then, calls into question the rationale of enacting "get tough" immigration policies, particularly against non-criminal aliens. Present-day proposals of immigration reform will not likely benefit public safety. Rather, Draconian immigration laws such as Arizona Senate Bill 1070 and Alabama House Bill 56 will likely undermine the very public safety that they were purportedly designed to protect.

An underlying context surrounding political debates on immigration is the question of whether public safety—an undeniable common good—is best secured through the use, show, or threat of force or sanction. Generally, there are two strategies available for obtaining obedience to laws: forced compliance and normative compliance. Forced compliance refers to the use of 
sanctions and punishments as an incentive (or disincentive) for behavior. Forced compliance is the foundation of nearly all deterrence based criminal policies; increasing the costs, certainty, and severity of sanctions is supposed to ensure the obedience of individuals to the law (see Zimring and Hawkins 1973; Nagin 1998). In contrast, normative compliance fosters obedience to the law based on the belief that those making the law have a right to do so and, by extension that the laws they create are in some way “just” (Tyler 1990). When individuals perceive that the law is unjust and illegitimate, they are more likely to become cynical of the intent and utility of the law and are more likely to disobey it.

Our study, as well as other research on legitimacy (Tyler 1990), stresses the Durkheimian idea that societies can and do regulate themselves more efficiently by fostering normative compliance with the law. Namely, individuals are less likely to break laws when they believe the laws are morally just and that the procedures and authorities charged with enforcing the laws are fair. While no society could do without some amount of forced compliance, the legitimacy perspective suggests that the common good is better served when compliance is developed normatively rather than at the edge of a sword.

We motivated our study by noting the trend in increasing deportations of illegal aliens in the post 9/11 era, particularly of non-criminal aliens. Indeed, over much of the past three years the Obama Administration has displayed more aggressive enforcement of immigration laws than the preceding Administration. A risk of such harsh enforcement is that immigrants will become alienated from the law, thereby undermining their willingness to cooperate with the law and even comply with the law. In a possible reverse of course, on August 18, 2011, the Obama Administration announced that it would suspend deportation hearings against illegal immigrants who pose minimal risk to public safety and national security (Pear 2011). Under this new policy, 
the Department of Homeland Security has been conducting case-by-case reviews of some 300,000 deportation filings, to ensure that illegal immigrants with criminal convictions are the focus of deportation instead of individuals who pose a minimal risk to safety and security. This shift in policy should impact public safety, but not in the way that immigration foes may think. The Obama Administration seemingly swapped a policy of forced compliance for one of normative compliance. To be sure, the Administration still intends to deport criminal aliens. Yet by redirecting enforcement away from lawful immigrants, this new strategy should enhance public safety by preventing the government from destroying the support for the law that is found in so many immigrant communities. 


\section{REFERENCES}

Beetham, David. 1991. The Legitimation of Power. London: MacMillan Education Ltd.

Bursik, Robert J., Jr., and Harold G. Grasmick. 1993. Neighborhoods and Crime: The Dimensions of Effective Community Control. New York: Lexington Books.

Butcher, Kristin F., and Anne M. Piehl. 1998. "Cross-City Evidence on the Relationship between Immigration and Crime.” Journal of Policy Analysis and Management 17:457-93.

Davies, Garth, and Jeffrey Fagan. 2012. "Crime and Policing in Immigrant Neighborhoods: Evidence from New York City.” The Annals of the American Academy of Political and Social Science 641. Forthcoming.

Fagan, Jeffrey, and Tracey Meares. 2008. "Punishment, Deterrence and Social Control: The Paradox of Punishment in Minority Communities.” Ohio State Journal of Criminal Law 6:173-229.

Fagan, Jeffrey, and Alexis Piquero. 2007. "Rational Choice and Developmental Influences on Recidivism among Adolescent Felony Offenders.” Journal of Empirical Legal Studies 4: $715-48$.

Fagan, Jeffrey, and Tom T. Tyler. 2005. "Legal Socialization of Children and Adolescents." Social Justice Research 18:217-42.

French, John R. P., and Bertram Raven. 1959. “The Bases of Social Power.” In Studies in Social Power, edited by Dorwin Cartwright. Ann Arbor: University of Michigan Press.

Graif, Corina, and Robert J. Sampson. 2009. "Spatial Heterogeneity in the Effects of Immigration and Diversity on Neighborhood Homicide Rates.” Homicide Studies 13:242-60.

Hagan, John, and Alberto Palloni. 1998. "Immigration and Crime in the United States.” In The Immigration Debate: Studies on the Economic, Demographic, and Fiscal Effects of Immigration, edited by James P. Smith and Barry Edmonston. Washington, DC: National Academy Press.

Homeland Security Advisory Council. 2011. Task Force on Secure Communities: Findings and Recommendations. Washington, DC: Department of Homeland Security. Retrieved September 18, 2011 (http://www.dhs.gov/xlibrary/assets/hsac-task-force-on-securecommunities-findings-and-recommendations-report.pdf).

Jackson, Kenneth L., and John Manbeck. 1998. The Neighborhoods of Brooklyn. New Haven: Yale University Press. 
Kaufmann, Daniel, Aart Kraay, and Massimo Mastruzzi. 2010. The Worldwide Governance Indicators: Methodology and Analytical Issues. World Bank Policy Research Working Paper No. 5430. Available at SSRN: http://ssrn.com/abstract=1682130.

Kennedy, Peter. 1998. A Guide to Econometrics. $4^{\text {th }}$ Edition. Cambridge, MA: The MIT Press.

Kirk, David S., and Mauri Matsuda. 2011. "Legal Cynicism, Collective Efficacy, and the Ecology of Arrest.” Criminology 49:443-72.

Kirk, David S., and Andrew V. Papachristos. 2011. "Cultural Mechanisms and the Presence of Neighborhood Violence.” American Journal of Sociology 116:1190-233.

Kornhauser, Ruth. 1978. Social Sources of Delinquency. Chicago: University of Chicago Press.

Lee, Matthew T., Ramiro Martinez Jr., and Richard Rosenfeld. 2001. "Does Immigration Increase Homicide? Negative Evidence from Three Border Cities.” Sociological Quarterly 42:559-80.

Morenoff, Jeffrey D., and Avraham Astor. 2006. "Immigrant Assimilation and Crime: Generational Differences in Youth Violence in Chicago.” In Immigration and Crime: Race, Ethnicity, and Violence, edited by R. Martinez, Jr. and A. Valenzuela, Jr. New York: New York University Press.

Nagin, Daniel S. 1998. "Criminal Deterrence Research at the Outset of the Twenty-First Century.” In Crime and Justice: An Annual Review of Research, vol. 23, edited by Michael Tonry. Chicago: University of Chicago Press.

Papachristos, Andrew V., Tracey L. Meares, and Jeffrey Fagan. 2011. "Why Do Criminals Obey the Law? The Influence of Legitimacy and Social Networks on Active Gun Offenders.” Yale Law \& Economics Research Paper No. 373; Columbia Public Law Research Paper No. 09199. Available at SSRN: http://ssrn.com/abstract=1326631.

Pear, Robert. 2011. Fewer Youths to Be Deported in New Policy. New York Times, 18 August. Retrieved August 19, 2011 (http://www.nytimes.com/2011/08/19/us/19immig.html?_r=2\&ref=politics).

Sampson, Robert J. 2011. Great American City: Chicago and the Enduring Neighborhood Effect. Chicago: University of Chicago Press.

Sampson, Robert J., and Dawn Jeglum Bartusch. 1998. "Legal Cynicism and (Subcultural) Tolerance of Deviance: The Neighborhood Context of Racial Differences.” Law \& Society Review 32:777-804.

Sampson, Robert J., Jeffrey D. Morenoff and Stephen Raudenbush. 2005. "Social Anatomy of Racial and Ethnic Disparities in Violence.” American Journal of Public Health 95:224-32. 
Shaw, Clifford R., and Henry D. McKay. 1942. Juvenile Delinquency and Urban Areas. Chicago: University of Chicago Press.

Skogan, Wesley, and Kathleen Frydl. 2003. Fairness and Effectiveness In Policing: The Evidence. Washington: National Academy Press.

Sunshine, Jason, and Tom R. Tyler. 2003. "The Role of Procedural Justice and Legitimacy in Shaping Public Support for Policing.” Law and Society Review 37:555-89.

Tyler, Tom R. 1990. Why People Obey The Law. New Haven: Yale.

------. 2010. Why People Cooperate. Princeton NJ: Princeton University Press.

Tyler, Tom R., and Jeffrey Fagan. 2008. "Legitimacy, Compliance and Cooperation: Procedural Justice and Citizen Ties to the Law.” Ohio State Journal of Criminal Law 6: 231-75.

Tyler, Tom R., Stephen Schulhofer, and Aziz Huq. 2010. "Legitimacy and Deterrence Effects in Counter-Terrorism Policing: A Study of Muslim Americans.” Law and Society Review 44: 365-401.

U.S. Department of Homeland Security [DHS]. 2010. Yearbook of Immigration Statistics: 2009. Washington: U.S. Department of Homeland Security, Office of Immigration Statistics. Retrieved August 19, 2011 (http://www.dhs.gov/xlibrary/assets/statistics/yearbook/2009/ois_yb_2009.pdf).

U.S. Government Accountability Office [GAO]. 2009. Immigration Enforcement: Better Controls Needed over Program Authorizing State and Local Enforcement of Federal Immigration Laws. GAO-09-109. Report to Congressional Requesters. Washington, DC: U.S. Government Accountability Office. Retrieved August 17, 2011 (http://www.gao.gov/products/GAO-09-109).

U.S. Immigration Commission. 1911. Immigration and Crime, Vol. 36. Washington, DC: U.S. Government Printing Office.

Wickersham Commission. 1931. National Commission on Law Observance and Enforcement: Report on Crime and the Foreign Born, No 10. Washington, DC: U.S. Government Printing Office.

Weber, Max. 1968. Economy and Society (G Roth and C Wittich, eds.). New York: Bedminster Press.

Zimring, Franklin E., and Gordon J. Hawkins. 1973. Deterrence: The Legal Threat in Crime Control. Chicago: University of Chicago Press. 
Table 1. The Relationship between Immigration and Legal Cynicism

\begin{tabular}{|c|c|c|c|c|c|c|c|c|}
\hline & \multicolumn{2}{|c|}{ Model 1} & \multicolumn{2}{|c|}{ Model 2} & \multicolumn{2}{|c|}{ Model 3} & \multicolumn{2}{|c|}{ Model 4} \\
\hline & \multicolumn{2}{|r|}{ Robust } & \multicolumn{2}{|r|}{ Robust } & \multicolumn{2}{|r|}{ Robust } & \multicolumn{2}{|r|}{ Robust } \\
\hline & Coef. & Std. Err. & Coef. & Std. Err. & Coef. & Std. Err. & Coef. & Std. Err. \\
\hline Intercept & 0.089 & $(0.072)$ & 0.160 & $(0.174)$ & 0.206 & $(0.164)$ & 0.074 & $(0.072)$ \\
\hline Concentrated Poverty & 0.267 & $(0.042) * * *$ & 0.261 & $(0.043) * * *$ & 0.258 & $(0.043) * * *$ & 0.273 & $(0.042) * * *$ \\
\hline Residential Stability & 0.070 & $(0.058)$ & 0.062 & $(0.060)$ & 0.043 & $(0.068)$ & 0.074 & $(0.057)$ \\
\hline Population Density & -0.008 & $(0.013)$ & -0.011 & $(0.014)$ & -0.008 & $(0.014)$ & -0.012 & $(0.014)$ \\
\hline Neighborhood Disorder & 0.025 & $(0.107)$ & 0.024 & $(0.108)$ & 0.037 & $(0.110)$ & 0.013 & $(0.105)$ \\
\hline Immigrant Concentration, 2000 & -0.068 & $(0.025) * *$ & -0.054 & $(0.039)$ & -0.059 & $(0.030) *$ & & \\
\hline Language Diversity & & & -0.133 & $(0.308)$ & & & & \\
\hline Recent Immigrants & & & & & -0.006 & $(0.008)$ & & \\
\hline Immigrant Concentration, 1990 & & & & & & & -0.061 & $(0.030) *$ \\
\hline Resid. Change Imm. Conc., 1990 to 2000 & & & & & & & -0.172 & $(0.102) *$ \\
\hline R-squared & 0.5 & & 0. & & 0. & & 0.5 & \\
\hline
\end{tabular}

$* p<.05{ }^{* *} p<.01 * * * p<.001$ (one-tailed test). 
Table 2. The Duality of Justice as a Predictor of Legal Cynicism

\begin{tabular}{|c|c|c|c|c|}
\hline & \multicolumn{2}{|c|}{ Model 5} & \multicolumn{2}{|c|}{ Model 6} \\
\hline & \multicolumn{2}{|r|}{ Robust } & \multicolumn{2}{|r|}{ Robust } \\
\hline & Coef. & Std. Err. & Coef. & Std. Err. \\
\hline Intercept & 0.062 & $(0.067)$ & 0.024 & $(0.074)$ \\
\hline Concentrated Poverty & 0.215 & $(0.045) * * *$ & 0.141 & $(0.059) * *$ \\
\hline Residential Stability & 0.060 & $(0.055)$ & 0.014 & $(0.052)$ \\
\hline Population Density & -0.010 & $(0.013)$ & -0.011 & $(0.014)$ \\
\hline Neighborhood Disorder & -0.033 & $(0.110)$ & -0.013 & $(0.111)$ \\
\hline Immigrant Concentration, 1990 & -0.042 & $(0.029)$ & -0.087 & $(0.035) * *$ \\
\hline Resid. Change Imm. Conc., 1990 to 2000 & -0.064 & $(0.112)$ & -0.133 & $(0.113)$ \\
\hline Procedural Justice & -0.287 & $(0.112) * *$ & -0.247 & $(0.116) *$ \\
\hline Origin Rule of Law & & & -0.359 & $(0.153) * *$ \\
\hline R-squared & 0.5 & & 0.5 & \\
\hline
\end{tabular}

$* \mathrm{p}<.05 * * \mathrm{p}<.01 * * * \mathrm{p}<.001$ (one-tailed test). 
Table 3. The Relationship between Immigration and Public Cooperation with the Police

\begin{tabular}{|c|c|c|c|c|c|c|}
\hline & \multicolumn{2}{|c|}{ Model 1} & \multicolumn{2}{|c|}{ Model 2} & \multicolumn{2}{|c|}{ Model 3} \\
\hline & \multicolumn{2}{|r|}{ Robust } & \multicolumn{2}{|c|}{ Robust } & \multicolumn{2}{|r|}{ Robust } \\
\hline & Coef. & Std. Err. & Coef. & Std. Err. & Coef. & Std. Err. \\
\hline Intercept & 0.014 & $(0.090)$ & 0.029 & $(0.091)$ & 0.297 & $(0.180)$ \\
\hline Concentrated Poverty & -0.187 & $(0.049) * * *$ & -0.142 & $(0.057) * *$ & -0.163 & $(0.055)^{* *}$ \\
\hline Residential Stability & 0.141 & $(0.059) * *$ & 0.153 & $(0.059) * *$ & 0.123 & $(0.065) *$ \\
\hline Population Density & 0.003 & $(0.014)$ & 0.002 & $(0.015)$ & -0.007 & $(0.017)$ \\
\hline Neighborhood Disorder & 0.082 & $(0.115)$ & 0.086 & $(0.116)$ & 0.085 & $(0.111)$ \\
\hline Immigrant Concentration, 2000 & 0.082 & $(0.036) *$ & 0.071 & $(0.036) *$ & 0.124 & $(0.042) * *$ \\
\hline Legal Cynicism & & & -0.167 & $(0.099) *$ & -0.178 & $(0.099) *$ \\
\hline Language Diversity & & & & & -0.501 & $(0.258) *$ \\
\hline R-squared & 0.3 & & 0.4 & & 0.4 & \\
\hline
\end{tabular}

$* \mathrm{p}<.05 * * \mathrm{p}<.01 * * * \mathrm{p}<.001$ (one-tailed test). 
Figure 1. A Conceptual Model of Legal Cynicism and its Consequences

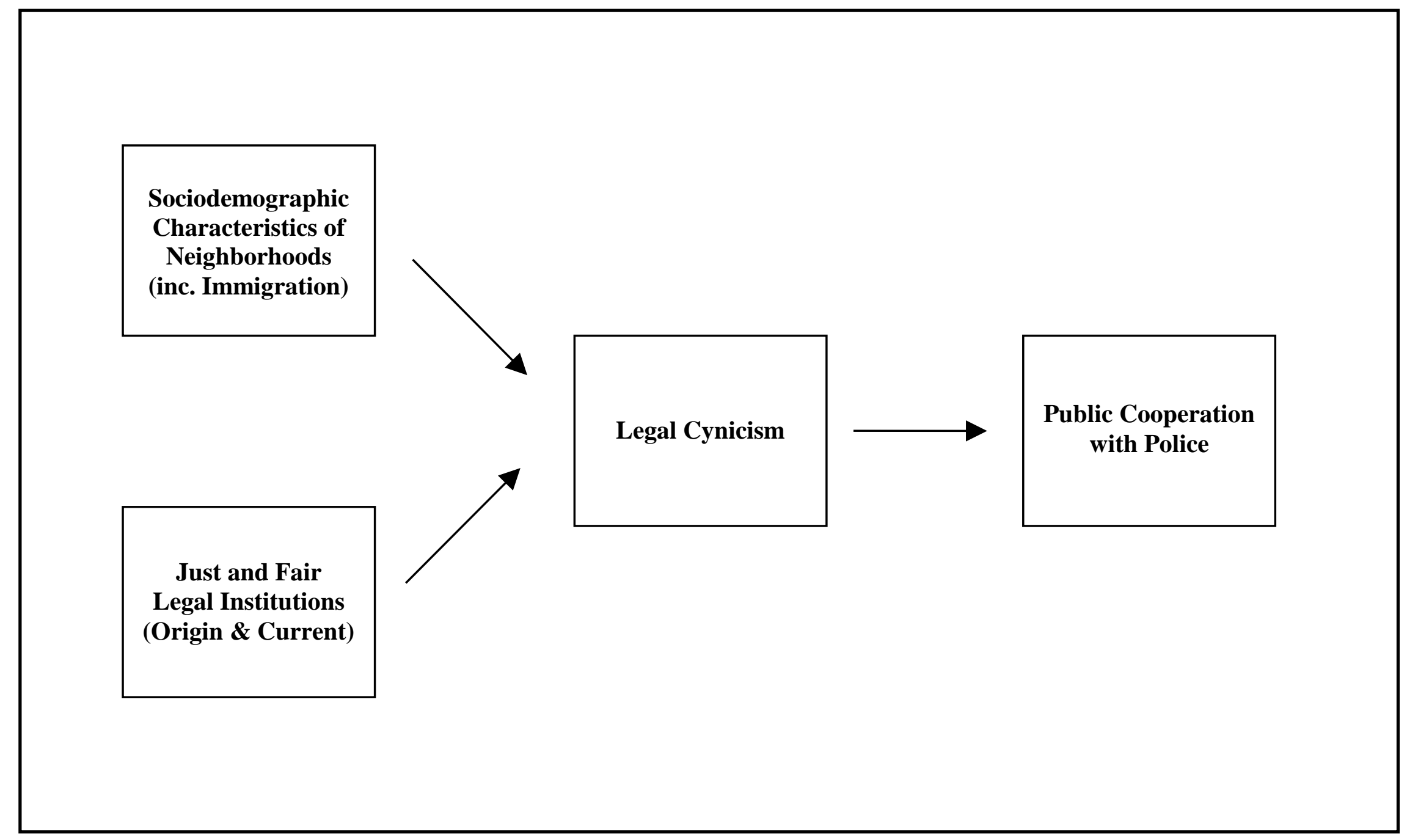


Figure 2. Foreign-born Population in New York City, 2000 Census

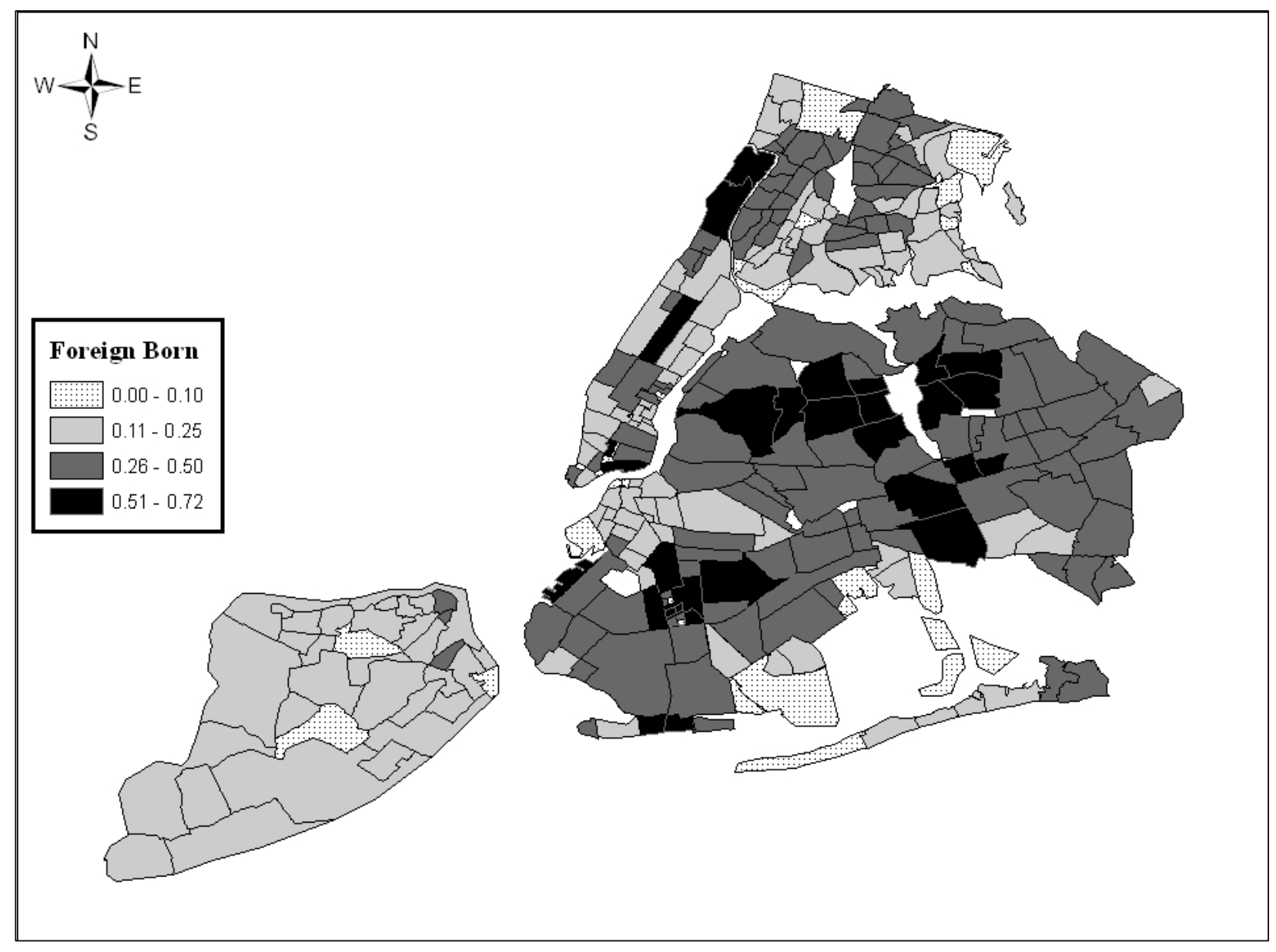


Figure 3. Standard Deviation Change in Legal Cynicism per Standard Deviation Change in Neighborhood Characteristics

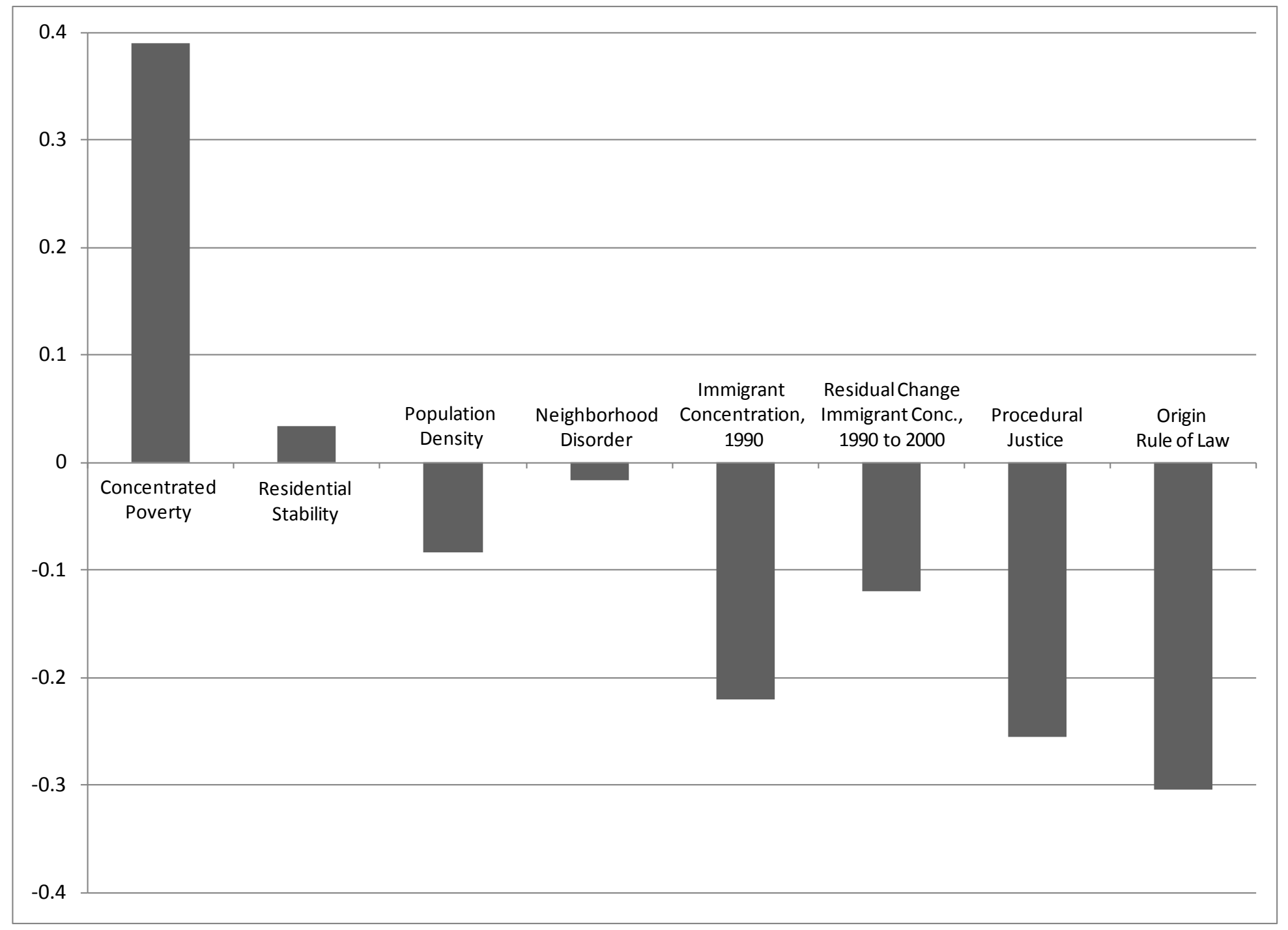

